\title{
Marginal and Media Productivity of Labor on Table Grape Harvest
}

\author{
Espíndola Rodrigo Sebastián ${ }^{1}$, Gennari Alejandro ${ }^{2}$ \\ ${ }^{1}$ National Institute of Agricultural Technology (INTA), Caucete Rural Extensión Agency, San Juan, Argentina \\ ${ }^{2}$ Agronomic Engineering School, Cuyo National University, Mendoza, Argentina
}

Email address:

espindola.rodrigo@inta.gob.ar (E. R. Sebastián)

\section{To cite this article:}

Espíndola Rodrigo Sebastián, Gennari Alejandro. Marginal and Media Productivity of Labor on Table Grape Harvest. Advances in Bioscience and Bioengineering. Vol. 8, No. 2, 2020, pp. 38-41. doi: 10.11648/j.abb.20200802.15

Received: June 30, 2020; Accepted: July 17, 2020; Published: August 10, 2020

\begin{abstract}
In recent years in San Juan, Argentina the lack of manpower to harvest, clean and packing export table grape caused serious economic problems and it is the most important reason that explains the disappearance of Argentina in this area. Labor is very expensive and it is the highest production cost. Also it is unknown in Argentina whether it is convenient hiring labor or not. In the other hand the efficient used of labor is disregarded and buying hard technology in replacement of labor is very difficult in table grape production. The objective of this study is to measure the mean and marginal labor productivity during harvesting, packing and to describe the process. A sectional study was carry out with 144 interviews in seven districts in San Juan. The harvesting and cleaning time was measured and the number of table grape boxes done in a certain period of time too. We observed each harvesting and packing group made up of one to four people and that when the number of workers per group increased, the number of boxes per worker per hour had reduced from 4 to 1 resulting in a negative marginal productivity. Up to $20 \%$ of the effective working time a day was lost due to failures in the work organization
\end{abstract}

Keywords: Harvesting, Cost, Working Day

\section{Introduction}

Half the labor needed for table grape production is required during harvesting season [1] as it happens in intensive crops [2]. Most tasks should be made by hand [3] and for this reason there is a high labor concentration in a few months every year [2]. For example, in earlier varieties $77 \%$ of labor is hired between October and December [4]. On the other hand, in San Juan, labor used for wines production needs permanent and temporary workers, and between 89 and 105 working days per season are required [3].

In Mendoza premium wines production need between 52 and 56 working days in each season [5]. According to some studies more qualified workers are needed when higher technology is used, also the more technology is used the more permanent labor is needed. According to that, the number of working days used in every season will depend on the crop features, the production destination and the grape variety [4].

The cycle of table grape production begins during bud dormancy with pruning in July [2]. In spring, some tasks begin, such as irrigation, soil management, weed control and diseases control [3]. In September and October, shoot elimination is carried out [4]. Shoots without any bunches and lateral shoots are eliminated too [5]. After that some leaves are taken out to reduce the damage they do to bunches, getting a better exposure to light and to chemical spraying. The bunch thinning is made from October to November and the bunch length regulation from November to December [6]. These tasks allow to regulate the number of bunches per vine from 60 to 40 and also the length of each bunch [4]. Bunches whose position is not the correct one, are repositioned. A chemical flower elimination is made when flowers bloom [6].

In December depending on the variety harvesting begins [3]. This activity needs harvesters who can identify ripen bunches, because not all bunch ripen at the same time, so harvesting takes longer [4]. Clusters that have already been harvested are put in plastic boxes that allow a total weight of $10 \mathrm{~kg}$. Finally, the grapes are usually packed in the vineyard. Between 202 and 209 working days a year are needed for a complete production cycle [2]. Miranda and Novello [5] estimated that between 900 and 1100 hours are needed per hectare to produce table grapes [7]. Most of this time is spent 
on pruning, bunch pruning and harvesting. All these jobs are paid daily and there is no data available [8].

From June to September pruning is carried out and it takes $21 \%$ of the working days spent in a year and from October to November the elimination of shoots, bunches and leaves is carried out, which takes $42 \%$ of the working days [6]. From December to April harvesting is the main activity (37\%) and the most difficult task because of i) the number of harvesters, ii) the table grape varieties ripening at different times and iii) the mechanization is not possible [9]. All these jobs imply an increase of the labor demand [8]. For these reasons the goals of this study are to measure the harvesting mean and marginal productivity in table grape production during the packing process, and to characterize the labor organization. In this way, it could be supposed there are more than two organization structures in every single table grape harvesting and packing group, and every time the number of harvesters increase in each group, the number of table grape boxes produced per hour decrease.

\section{Materials and Methods}

For this study we focused on the districts of Pocito, Caucete, Rawson, Albardón, 9 de Julio, Zonda y Ullum, San Juan, Argentina, as the main producer that export table grape. Harvesters were interviewed between the 2015 and 2017 seasons. The quantity of grape produced and exported at that time [10] were estimated. With these values the number of interviews to do was calculated [11]. For that the modal value per day of kilograms each harvester usually does was taking into account (28 $8.2 \mathrm{~kg}$ boxes) [9]. A harvester in that period of time is supposed to work at least 30 days. In this way each harvester could pack $6,888 \mathrm{~kg} /$ season and as a consequence 3,446 harvesters are needed to pick up 23,742,000 million $\mathrm{kg}$ [12].

A table of size sample for finite populations was used [12]. With a 95\% goodness of fit and a $10 \%$ error, for 3,500 potential individuals, 97 interviews are needed [13], which means $2.7 \%$ sampling fraction. To reduce the error the sampling fraction was increased to $4.2 \%$ (144 interviews) [12].

Since harvesting depends on multiple factors, interviews were conducted according to the harvest opportunity on the farms in the selected areas. A minimum of 16 interviews was carried out in each district. In this way we got the total number of interviews we needed.

Multivariate descriptive methods, frequency analyses, chisquare test and crosstabs were calculated to determine the relationship between variables.
The variables analyzed were: the size of boxes, the way the different groups of workers do their job, picking and cleaning time, harvest beginning and ending time, the total number of boxes filled with grape in a certain time, the time required to fill one box, picking and cleaning total time, the number of harvesters per group, the number of boxes each worker to do per hour, the time wasted along the process, the workers average age per group, and the experience of each harvesting group. The task distribution variable was determined by the way harvesting and packing were done. We consider a) if always the same person did de same activity (only harvesting, only cleaning, only weighing, only packing) or b) if they took turns to do the activities and how it happened. Regarding the harvesting variable we took into account whether the worker packed the grapes which had previously been cleaned or not. The waste of time variable involved any kind of situation which made the harvest difficult (lack of supplies, lack of scales, bad grape quality or a combination of those factors). All data were processed with SPSS 15.0 program.

\section{Results}

The harvest (picking and then packing) usually begins at 7:00 am and after e break it restarts at 2:00 pm. Every harvest group has 1 to 4 workers (1.72 mean), 25.28 years of age and 5.17 year experience on average. Harvesting mean time is 1 hour 20 minutes before the beginning of packing. In the study, $50.76 \%$ of the harvesting groups did a combination of tasks (harvesting, cleaning, weighing and packing) and $49.32 \%$ did not. The mean number of boxes per hour-worker is 3.71 when there is a combination of tasks and 3.86 boxes per hour-worker when there is not. The modal value when a combination of tasks is carried out is form 3.34 to 3.46 boxes per hour and if there is not a combination of tasks every single worker packs $3.48-3.65$ boxes. In the study, $87.84 \%$ of workers harvested grapes before cleaning and packing those ( 3.72 boxes per worker-hour), a $12.16 \%$ did not harvest and only cleaned and packed (4.22 boxes per worker-hour).

$48.64 \%$ of the workers belonged to groups made up of two persons; $41.21 \%$ represented only one single worker; $6.75 \%$ to three workers per group, and $3.37 \%$ to four workers per group. The average number of boxes per worker-hour was 4.90 with two workers into each group; 3.14 with only one worker; 2.70 with three workers and 1.6 with four workers. This means that when one worker was added into each group, the production decreases (fewer boxes per worker-hour): 35\%; 13.7\% and 40\%.

Table 1. Descriptive statistics for the number of boxes packed per worker-hour according to the number of workers in each group. Marginal and mean labor productivity measured in boxes per worker-hour.

\begin{tabular}{|c|c|c|c|c|c|}
\hline Workers per group & Number of boxes per worker-hour & & Workers per group & Number of boxes per worker-hour & \\
\hline \multirow{4}{*}{1} & Mean productivity & 4.9 & \multirow{4}{*}{ 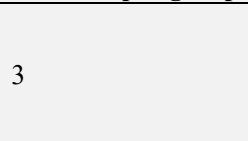 } & Mean productivity & 2.7 \\
\hline & Marginal productivity & 4.9 & & Marginal productivity & -0.4 \\
\hline & Minimum & 0 & & Minimum & 0 \\
\hline & Maximo & 10.2 & & Maximo & 4.7 \\
\hline \multirow{4}{*}{2} & Mean productivity & 3.1 & \multirow{4}{*}{4} & Mean productivity & 1.6 \\
\hline & Marginal productivity & -1.8 & & Marginal productivity & -1.1 \\
\hline & Minimum & 0 & & Minimum & 0.7 \\
\hline & Maximo & 8.8 & & Maximo & 2.3 \\
\hline
\end{tabular}


Huber index shows that if a harvester works alone harvesting and packing table grapes he does 4.81 boxes per hour. If two harvesters do the same the job efficiency decreases $42.82 \%$; if three people do the job the decrease is $41.37 \%$; and in the case of four people the decrease is $64.65 \%$. Regarding the problems $31.8 \%$ of harvesters said that they had problems related to the lack of harvest supplies, the lack of weight scales and the bad quality of grapes. $20.9 \%$ pointed out that the grape quality was not good enough; $14.9 \%$ said there was problems related to the lack of harvest supplies and $8.8 \%$ had problems with the lack of weight scales; only, $23.6 \%$ did not have any difficulties.

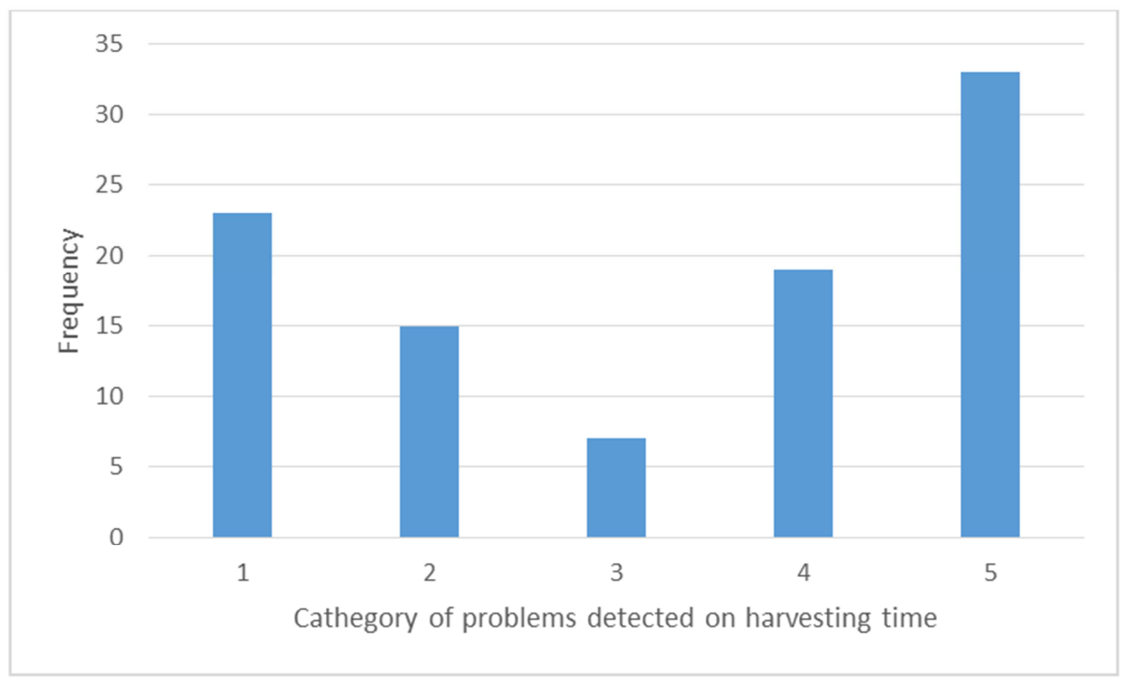

Figure 1. Frequency analysis waste of time variable: $0=$ no problems; $1=$ lack of supplies; $2=$ lack of scales; $3=$ bad grape quality; $4=$ a mix of factors.

\section{Discussion}

Neiman [14] showed that farmers pick the best chance with regard to job organization according to their economic goals [15]. Opposite to that, this study shows that San Juan table grapes farm pickers choose who to work with; it could be between one to four workers and that is not a company decision. The distribution of workers groups is as follows: $41.21 \%$ only one person; $48.64 \%$ two people; $6.75 \%$ three people and $3.37 \%$ four people harvesting and packing.

The arrival of Agro export companies let an intensive use of labor in Latin America [3]. In fact we measured 3.78 boxes of table grapes per worker-hour and up to 10.28 boxes as a maximum. If the farm workers are using $5.5 \mathrm{~kg}$ boxes, each of them will pack $20 \mathrm{~kg}$ of table grapes on a working day and if they are using $8.2 \mathrm{~kg}$ boxes harvesters will be able to harvest almost $31 \mathrm{~kg}$ per working day (on average). Under that situation every day in a farm will be need to hire between 322 and 500 harvesters depending on the kind of boxes they are using at that moment.

Radonich and others [16], and Battistella and Novello [17], said there are not enough workers for harvesting and doing all the tasks on farms. For that reason it is important to optimize labor used. The results of this study let us know that the harvest begins at 7:00 am; however the really harvest begins at $8: 38$ on average, so a worker spends $20 \%$ of their time (1 hour 38 minutes) doing others thing but not harvesting what is undesirable for optimizing labor used. On the other hand the best table grape production in boxes per hour is linked only to one or two workers into each working group. One worker does 4.87 boxes per hour and four workers together do 1.7 boxes per hour; this means the harvest of table grapes has a negative marginal productivity of labor.

Allamad [18] said it is necessary to reduce production costs to increase the farms profit. Also he and Espindola and others [11] said labor is the most expensive factor of production (between $60 \%$ and $80 \%$ ). This paper indicates that to get better results about harvest cost every single worker should do more than 3.78 boxes per hour.

It is possible to increase labor productivity on farms by using new technology and hiring agricultural services [19]. The incorporation of technology should be linked to the process of the organization of table grapes harvest [11]. If two people are working together it is the same with respect to the number of boxes per hour they do whether they exchange tasks or not. When the number of workers in every single group increases the only change it is the number of boxes each worker-hour (the more workers in each group, the fewer boxes per worker-hour). Also $10.1 \%$ of harvesters could not to do their job at all because of the lack of supplies, the lack of weight scales or the bad quality of grapes.

In 1968 Myrdal [20] said that underemployment could be understood as leisure time. This research verifies that the more workers the fewer boxes per hour are done. Battistella and Quaranta [4] and Pérez [21] observed that between 202 and 209 working days are necessary per hectare for table grape production and more than $50 \%$ of these days are used for harvesting. If a company spends 800 hours on harvesting and if the number of boxes per hour is reduced from four to three, The Company will lose between $4,400 \mathrm{~kg}$ and $6,560 \mathrm{~kg}$ of table grapes as an opportunity cost. Miranda and Novello 
[5] said harvesting is the most difficult task in all the production cycle. For this reason every company should pay attention to the harvest organization and get more than 10 boxes per harvester- hour which is possible only with skilled workers.

\section{Conclusion}

The harvest in Argentina is organized by workers who make decisions about the way of using resources available. The company delegates this responsibility that could lead to several mistakes.

If the harvest tasks are flexible between workers (pickers and packers), the job is more efficient than when workers are making a specific task (only harvest or only pack).

A waste of time up to $20 \%$ of a working day it is possible and it happens between the moment the workers arrive in a farm and the harvest begins. On average 1 hour and 20 minutes is wasted to harvest grapes before packing them.

A person working alone is more efficient than two or more people working together when harvesters are not enough in a full harvest and packing process. The labor mean and marginal productivity measured by boxes per hour-worker decreases every time one person is added to a group of harvesters.

The best organization is related to no more than two people per group. More people can increase the number of boxes per group but the labor productivity per person will decrease.

All the organization factors should be optimized by the company before the harvest begins to get better profits. If all of this is not taken into account the company can lose up to $6,560 \mathrm{~kg}$ of table grape every 800 hour during the harvest season.

Anytime the number of harvesters is increased in every single working group the number of boxes per worker-hour will decrease.

\section{References}

[1] FAO-OIV. Table and Dried Grapes. Published by The Food and Agriculture Organization of the United Nations and The International Organization of Vine and Wine. 2016. págs 64.

[2] M. Fidelibus; A. El-kereamy; G Zhuang; D. Haviland; K. Hembree and D. Stewart. Sample Costs to Establish and Produce Table Grapes. Published by Agricultural Issues Center and Department of Agricultural and Resource Economics, UC Davis. 2018. págs 26.

[3] J. Dominguez. Crecimiento, desarrollo y recursos humanos. Agronomía y forestal 29, Santiago: Universidad Católica de Chile., 2006. págs 6-7.

[4] M. Battistella, and G. Quaranta. "La demanda de mano de obra en uva de mesa, provincia de San Juan". [aut. libro] G. Neiman. In Estudio sobre la demanda de trabajo en el agro argentino. Buenos Aires: ciccus, 2010, págs 237-256.

[5] O. Miranda and R. Novello. Documento de la cadena de uva de mesa. San Juan: Programa Nacional de Frutales. INTA, 2006.

[6] M. Gandarillas Infante. Consolidación de la producción de uva de mesa. Encuentro Nacional del Agro. Copiapó, Chile. 2008.

[7] D. Pizzolato and L Goldfarb. "La demanda de mano de obra en uva para obtención de vinos finos, provincia de Mendoza". In Estudio sobre la demanda de trabajo en el agro argentino. Buenos Aires: Ediciones Ciccus, 2010, págs 271-284.

[8] P. Miranda Palacios. Optimización de la gestión del recurso humano en labores de poda y cosecha en parrones de uva de mesa. Universidad Nacional de Chile, Escuela de Posgrado. Santiago de Chile. 2013. págs 59.

[9] R. Espindola and O. Miranda. Análisis de la brecha tecnológica en la producción de uva de mesa sanjuanina. [ed.] CEISO. RIES N ${ }^{\circ} 4$ semestre Julio-Diciembre, Bueno Aires: s.n., 2011, Revista Interdisciplinaria de Estudios Sociales, pág. 19.

[10] SENASA. Reporte Comparativo del Comercio Exterior de Productos, Subproductos y Derivados de Origen Vegetal. San Juan: s.n., 2017.

[11] R. Espindola; M. Battistella and F. Pugliese. Productividad de la mano de obra en la obtención de uva de mesa. 3, Buenos Aires: Instituto Nacional de Tecnología Agropecuaria. EEA San Juan, 2012, Estudios Rurales, Vol. 1, págs. 104-127.

[12] M. Triola. Estadística. décima. Mexico: Pearson, 2009. págs. 904.

[13] R. Sierra Bravo. Técnicas de investigación social. 14. Madrid: Editorial Thomson, 2005. págs. 714.

[14] G. Neiman. "Las condiciones técnicas, sociales y laborales de la demanda de trabajo es el agro argentino". in Estudio sobre la demanda de trabajo en el agro argentino. Buenos Aires: Ediciones Ciccus, 2010.

[15] I. Gómez; M. Gómez Cruz and R. Schwentesius Rindermann. "Producción y comercialización de hortalizas orgánicas en México". In Agricultura de exportación en tiempos de globalización. México: Juan Pablos Editor, 1999, págs. 121158 .

[16] M. Radonich; N. Steimbreger and M. Ozino Caligaris. "Cosechando temporadas". In De golondrinas y otros migrantes. Buenos Aires: La colmena Editorial, 1999, págs. $53-58$

[17] M. Battistella and R. Novello. Impacto de los métodos de cosecha asistida sobre la productividad de la mano de obra en la vendimia de uva para vino y mosto. [ed.] INTA. 17, 2013, Ruralis, págs 4-8.

[18] M. Allamand. Productividad. Agronomía y Forestal 29. Vol. 2. [ed.] UCC. Santiago de Chile. 2006, pág. 10.

[19] A. Fernandez Besada and R Cáceres. "Demanda de mano de obra en olivo, provincia de Catamarca y La Rioja". [aut. libro] G Neiman. In Estudios sobre a demanda de trabajo en el agro argentino. Buenos Aires: Ciccus, 2010, págs. 219-236.

[20] G. Myrdal. "An inquiry into the poverty of nations". The Pelican Press. Londres. 1968.

[21] C. Perez. Técnicas de análisis multivariado de datos. Madrid: Pearson, 20004. págs. 646. 